\title{
KOMPETENSI MAHASISWA SEBAGAI CALON GURU DALAM MENGHADAPI ERA 4.0
}

\author{
M. Saufi ${ }^{1}$
}

\section{Pendidikan Guru Sekolah Dasar STKIP PGRI Banjarmasin muhammadsaufi@stkipbjm.ac.id (081952939029)}

\begin{abstract}
ABSTRAK
Pendidikan merupakan proyek jangka panjang dari suatu negara. Setidaknya inilah kenyataan yang kita hadapi di Indonesia dalam kurun waktu beberapa tahun ke belakang. Tidak bisa dipungkiri bahwa pendidikan di Indonesia masih dalam tahap perkembangan, berbeda dengan negara maju seperti Jepang dan Finlandia yang benar-benar fokus untuk mengembangkan dunia pendidikan. Pemerintah di sana bahu-membahu membuat suatu sistem yang bermuara pada kompetensi, dalam hal ini adalah siswa dan mahasiswanya. Kompetensi harus dimiliki oleh setiap orang dalam era sekarang ini, tidak terkecuali oleh seorang guru dan calon guru. Apabila seseorang tidak mempunyai kompetensi dalam dirinya, maka orang tersebut akan tersisih dengan sendirinya. Di era 4.0, isu-isu yang beredar adalah akan tergantikannya tenaga manusia dalam segala aspek. Tentu saja manusia-manusia yang cenderung monoton, pasif, dan stagnan. Bisa jadi suatu saat tenaga manusia akan digantikan dengan tenaga robot. Oleh karena itulah penting sekalinya adanya kompetensi bagi seorang guru dan calon guru. Artikel ini merupakan hasil dari kajian pustaka yang ditulis oleh pemakalah untuk mendekripsikan berbagai isu-isu di dunia Pendidikan saat ini, yaitu empat kompetensi yang harus dimiliki oleh seorang guru dan empat keterampilan lunak (softskill) yang diusung oleh Pak Mendikbud, Nadiem Makarim di era 4.0.
\end{abstract}

Kata Kunci: Calon Guru, Pendidikan Era 4.0

\section{PENDAHULUAN}

Bapak Ibu dosen dan mahasiswa STKIP PGRI Banjarmasin beserta para tamu dan undangan yang berbahagia, izinkan saya terlebih dahulu memperkenalkan diri, nama saya M. Saufi, saat ini saya ditugaskan untuk menjadi salah satu pengajar di UPPS PGSD STKIP PGRI Banjarmasin. Pada kesempatan kali ini, saya akan mempresentasikan hasil kajian pustaka yang baru saja saya tulis kemarin. Mungkin agak berbeda dari pemakalah sebelumnya yang menampilkan tulisan berdasarkan hasil penelitian yang telah dilaksanakan. Pada kesempatan kali ini juga, saya ingin menyampaikan beberapa yang lebih bersifat pratis agar mudah dipahami oleh mahasiswa sebagai calon guru, yakni tentang pandangan mereka terhadap dunia pendidikan saat ini. Yang lagi viral adalah terpilihnya Pak Nadiem Makarim sebagai 
Mendikbud RI pada usia 35 tahun. Beliau mulai dikenal beberapa tahun silam sebagai founder aplikasi Go-Jek. Pada 100 hari sejak dilantiknya beliau menjadi Kemendikbud, banyak program-program dan ide-ide yang beliau sampaikan yang menjadi bahan perbincangan di kalangan masyarakat. Dunia pendidikan yang dulunya tidak lagi menjadi perbincangan karena masih kalah oleh dunia politik dan ekonomi, dewasa ini ini mulai ramai lagi di perbincangkan. Saya sangat salut dengan Mas Menteri ini karena apa yang beliau inginkan dan impikan itu sangat sejalan dengan apa yang ingin saya kerjakan sejak dulu. Oleh karena itu, pada kesempatan kali ini, saya akan menyampaikan hasil tulisan saya berdasarkan apa yang saya pikirkan dan berdasarkan referensi yang saya ambil dari beberapa sumber termasuk di dalamnya beberapa gagasan dari Mas Menteri.

Pendidikan merupakan proyek jangka panjang dari suatu negara. Setidaknya inilah kenyataan yang kita hadapi di Indonesia dalam kurun waktu beberapa tahun ke belakang. Tidak bisa dipungkiri bahwa pendidikan di Indonesia masih dalam tahap perkembangan, berbeda dengan negara maju seperti Jepang dan Finlandia yang benar-benar fokus untuk mengembangkan dunia pendidikan. Pemerintah di sana bahu-membahu membuat suatu sistem yang bermuara pada kompetensi, dalam hal ini adalah siswa dan mahasiswanya.

Ketika saya masih menempuh pendidikan S2, saat itu Profesor saya bercerita tentang pengalaman beliau ketika menempuh studi di Jepang. Beliau mengatakan bahwa siswa sekolah dasar ketika pertama kali duduk di bangku sekolah yaitu kelas 1 2 dan 3 ditanyakan pertanyaan berikut, "Apa yang membuat kalian senang?" tanya guru kepada satu per satu siswa. Jawaban mereka pun bervariasi, ada yang senang bermain sepak bola, membaca, menulis, bermain game, melukis, menggambar, dan tidak sedikit pula yang gemar berhitung. Pada saat itu Profesor saya sedang melaksanakan kegiatan praktik mengajar matematika di sekolah dasar. Lantas, bagaimana dia bisa mengajarkan matematika untuk setiap anak seperti halnya ketika mengajar siswa SD di Indonesia.

Berdasarkan pengamatan beliau ketika mengajar di luar negeri, berdiskusi dengan guru pamong yang ada di sana, disimpulkan bahwa dalam mengajar di kelas tidak selayaknya suatu materi dibagikan atau diberikan kepada seluruh siswa, mengapa demikian? Hal ini disebabkan karena kompetensi siswa yang berbeda-beda Bahkan di dalam satu kelas sekalipun.

Pengalaman tersebut mengindikasikan bahwa pentingnya arti dari sebuah kompetensi. Hal ini sejalan dengan apa yang diungkapkan oleh Mas Menteri, Nadiem Makarim, bahwa paradigma pendidikan di Indonesia yang harus diubah. Perubahan tersebut adalah tentang mindset implementasi kurikulum Indonesia. Kurikulumkurikulum yang ada di Indonesia sampai dengan saat ini sudah sangat bagus dan 
terukur, akan tetapi kelemahannya adalah evaluasi dari implementasi kurikulum itu sendiri. Apakah implementasi kurikulum itu sudah sesuai dengan apa yang direncanakan di awal pada saat perancangan atau malah sebaliknya. Beliau menambahkan lagi bahwa muara pendidikan di Indonesia berakhir pada kompetensi yang akan dimiliki siswa maupun mahasiswa ketika mereka lulus nanti.

Menurut Kamus Besar Bahasa Indonesia versi online, kompetensi adalah kewenangan (kekuasaan) untuk menentukan (memutuskan sesuatu); kemampuan menguasai gramatika suatu bahasa secara abstrak atau batiniah. Pengertian kompetensi menurut Undang-Undang Nomor 13 Tahun 2013 adalah kemampuan kerja setiap individu yang mencakup aspek pengetahuan, keterampilan dan sikap kerja yang sesuai dengan standar yang ditetapkan. Sedangkan menurut Suparno (2012:27), kompetensi adalah kecapakan yang memadai untuk melakukan suatu tugas atau memiliki keterampilan dan kecakapan yang diisyaratkan.

\section{PEMBAHASAN}

Kompetensi harus dimiliki oleh setiap orang dalam era sekarang ini, tidak terkecuali oleh seorang guru dan calon guru. Apabila seseorang tidak mempunyai kompetensi dalam dirinya, maka orang tersebut akan tersisih dengan sendirinya. Di era 4.0, isu-isu yang beredar adalah akan tergantikannya tenaga manusia dalam segala aspek. Tentu saja manusia-manusia yang cenderung monoton, pasif, dan stagnan. Bisa jadi suatu saat tenaga manusia akan digantikan dengan tenaga robot. Oleh karena itulah penting sekalinya adanya kompetensi bagi seorang guru dan calon guru.

Lebih jauh dikatakan bahwa kompetensi guru adalah kemampuan seorang guru dalam melaksanakan kewajiban-kewajibannya secara bertanggungjawab dan layak. Dalam Pasal 28 Ayat 3 PP Nomor 19 Tahun 2015 tentang Standar Nasional Pendidikan disebutkan bahwa ada empat kompetensi yang harus dimiliki oleh seorang guru, yaitu kompetensi pedagogik, kepribadian, profesional, dan kepribadian.

\section{Kompetensi Pedagogik}

Kompetensi pedagogik meliputi pemahaman guru terhadap peserta didik, perancangan dan pelaksanaan pembelajaran, evaluasi hasil belajar, dan pengembangan peserta didik untuk mengaktualisasikan berbagai potensi yang dimilikinya. Secara rinci setiap subkompetensi dijabarkan menjadi indikator sebagai berikut.

- Memahami peserta didik secara mendalam memiliki indikator esensial: memahami peserta didik dengan memanfaatkan prinsip-prinsip perkembangan 
kognitif; memahami peserta didik dengan memanfaatkan prinsip-prinsip kepribadian; dan mengidentifikasi bekal ajar awal peserta didik.

- Merancang pembelajaran, termasuk memahami landasan pendidikan untuk kepentingan pembelajaran, memiliki indikator esensial: memahami landasan kependidikan; menerapkan teori belajar dan pembelajaran; menentukan strategi pembelajaran berdasarkan karakteristik peserta didik, kompetensi yang ingin dicapai, dan materi ajar; serta menyusun rancangan pembelajaran berdasarkan strategi yang dipilih.

- Melaksanakan pembelajaran memiliki indikator esensial: menata latar (setting) pembelajaran; dan melaksanakan pembelajaran yang kondusif.

- Merancang dan melaksanakan evaluasi pembelajaran memiliki indikator esensial: merancang dan melaksanakan evaluasi (assessment) proses dan hasil belajar secara berkesinambungan dengan berbagai metode; menganalisis hasil evaluasi proses dan hasil belajar untuk menentukan tingkat ketuntasan belajar (mastery learning); dan memanfaatkan hasil penilaian pembelajaran untuk perbaikan kualitas program pembelajaran secara umum.

- Mengembangkan peserta didik untuk mengaktualisasikan berbagai potensinya, memiliki indikator esensial: memfasilitasi peserta didik untuk pengembangan berbagai potensi akademik; dan memfasilitasi peserta didik untuk mengembangkan berbagai potensi non akademik.

\section{Kompetensi Kepribadian}

Kompetensi kepribadian merupakan kemampuan personal yang mencerminkan kepribadian yang mantap, stabil, dewasa, arif, dan berwibawa, menjadi teladan bagi peserta didik, dan berakhlak mulia. Secara rinci subkompetensi tersebut dapat dijabarkan sebagai berikut:

- Kepribadian yang mantap dan stabil memiliki indikator esensial: bertindak sesuai dengan norma hukum; bertindak sesuai dengan norma sosial; bangga sebagai guru; dan memiliki konsistensi dalam bertindak sesuai dengan norma.

- Kepribadian yang dewasa memiliki indikator esensial: menampilkan kemandirian dalam bertindak sebagai pendidik dan memiliki etos kerja sebagai guru.

- Kepribadian yang arif memiliki indikator esensial: menampilkan tindakan yang didasarkan pada kemanfaatan peserta didik, sekolah, dan masyarakat serta menunjukkan keterbukaan dalam berpikir dan bertindak.

- Kepribadian yang berwibawa memiliki indikator esensial: memiliki perilaku yang berpengaruh positif terhadap peserta didik dan memiliki perilaku yang disegani.

- Akhlak mulia dan dapat menjadi teladan memiliki indikator esensial: bertindak sesuai dengan norma religius (iman dan taqwa, jujur, ikhlas, suka menolong), dan memiliki perilaku yang diteladani peserta didik. 


\section{Kompetensi Profesional}

Kompetensi Profesional adalah penguasaan materi pembelajaran secara luas dan mendalam, yang mencakup penguasaan materi kurikulum mata pelajaran di sekolah dan substansi keilmuan yang menaungi materinya, serta penguasaan terhadap struktur dan metodologi keilmuannya.

- Menguasai materi, struktur, konsep, dan pola pikir keilmuan yang mendukung pelajaran yang dimampu

- Menguasai standar kompentensi dan kompetensi dasar mata pelajaran/bidang pengembangan yang dimampu

- Mengembangkan materi pembelajaran yang dimampu secara kreatif.

- Mengembangkan keprofesionalan secara berkelanjutan dengan melakukan tindakan reflektif

- Memanfaatkan TIK untuk berkomunikasi dan mengembangakan diri.

\section{Kompetensi Sosial}

Kompetensi Sosial adalah kemampuan guru untuk berkomunikasi dan bergaul secara efektif dengan peserta didik, tenaga kependidikan, orang tua/wali peserta didik, dan masyarakat sekitar.

- Bersikap inkulif, bertindak obyektif, serta tidak diskriminatif karena pertimbangan jenis kelamin, agara, raskondisifisik, latar belakang keluarga, dan status sosial keluarga.

- Berkomunikasi secara efektif, empatik, dan santun dengan sesama pendidik, tenaga kependidikan, orang tua dan masyarakat.

- Beradaptasi di tempat bertugas di seluruh wilayah RI yang memiliki keragaman sosial budaya.

- Berkomunikasi dengan lisan maupun tulisan.

Pak Nadiem mengatakan bahwa "Sekarang, kompetensi adalah hal yang utama, diikuti berbagai keterampilan. Keterampilan tak terbatas pada hal teknis dan kognitif, tetapi juga keterampilan lunak, seperti empati, kreativitas, kemampuan berkomunikasi, dan bisa berkolaborasi,"

Oleh karena itu, 4 keterampilan lunak (softskill) yang diusung oleh Pak Mendikbud, Nadiem Makarim di era 4.0, yaitu

- Empati, yaitu empati adalah penerimaan terhadap perasaan orang lain dan dapat meletakkan diri kita pada tempat orang tersebut (Alfred Adler). 
- Kreatif, yaitu suatu proses pemikiran yang membantu mencetuskan berbagai gagasa baru yang merupakan salah satu sifat manusia yang dibentuk dari proses pengalaman sehingga menyebabkan orang tersebut bisa terus memperbaiki dan mengembangkan dirinya (Anderos: 1961).

- Komunikatif, yaitu pengertian komunikatif yaitu keadaan saling dapat berhubungan (mudah dihubungi), dan juga mudah dipahami (dimengerti).

- Kolaboratif, yaitu kerjasama atau kolaborasi.

\section{SIMPULAN}

Empat kompetensi dan empat keterampilan lunak inilah yang harus dimiliki oleh mahasiswa terutama mahasiswa calon guru agar bisa mengajar di sekolah baik itu SD, SMP, dan SMA. Era sekarang ini bukan lagi menjadi era di mana kita harus menunggu perintah dan instruksi dari seorang dosen, tetapi hal baik, impian baik niat yang baik untuk meningkatkan kualitas diri dalam pengembangan ilmu seperti kegiatan ini harus segera diwujudkan. Terkadang hal yang baik selalu dipaksakan pada awal mulanya, tetapi pada akhirnya mahasiswa memahami bahwa ajakannya selama ini merupakan sesuatu yang sangat bermanfaat bagi dirinya ketika dia lulus kuliah. Oleh karena itu, mulai dari sekarang siapkan diri pribadi masing-masing untuk menjadi sarjana muda, calon guru yang memiliki wawasan luas, out of the box, dan tidak serta merta ingin masuk dalam zona aman.

\section{DAFTAR RUJUKAN}

Aziz, A. A. (2015). Mutiara Pendidikan Karakter. Jakarta: Halimun Media Citra.

Budimansyah, D. (2012). Perancangan Pembelajaran Berbasis Karakter. Bandung: Widya Aksara Press.

Kompasiana.com. (2015, 17 Juni). Teori Kepribadian menurut Alfred Adler. Diakses pada 1 November 2019. Dari

Https://Www.Kompasiana.Com/Dfatmawati/557da2f5f67a61343d181a79/Teo ri-Kepribadian-Menurut-Alfred-Adler?Page $=$ All

Menteri. (2007). Peraturan Menteri Pendidikan dan Kebudayaan Nasional Nomor 16 Tentang Standar Kualifikasi Akademik dan Kompetensi Guru. 